\title{
The Problematic Relation between Direct Democracy and Accountability in Latin America: Evidence from the Bolivian Case
}

\author{
ANITA BREUER \\ University of Cologne, Germany
}

During the wave of constitutional reforms, which started in the late 1980s, Institutions of Direct Democracy (IDD) have been incorporated into most Latin American constitutions, and over the past fifteen years, an increased use of these instruments by Latin American governments has been observed. This article deals with two questions related to this phenomenon: (1) what motivated the adoption and use of these institutions; and (2) what consequences can be expected with regard to democratic accountability in the region?

To answer these questions, first, a classification of IDD is developed. In this, special attention is paid to the ability of the various types of IDD to introduce accountability into the representative structures of presidential systems. This classification is subsequently applied to analyse constitutional frameworks and direct democratic experience in the region. The findings suggest that the rise of IDD in Latin America was mainly induced by executive-legislative conflict and has done little to foster accountability. Finally, therefore, a detailed account of the specific constellation that led to the adoption of IDD in Bolivia is analysed in order to illustrate under which circumstances political actors choose to adopt and employ these tools.

Keywords: direct democracy, referendums, accountability, presidentialism, Bolivia.

\section{Introduction}

Worldwide, direct democratic practices have gained importance over the past few decades. Institutions of Direct Democracy (IDD) are increasingly added to new constitutions and, increasingly, important issues are decided by popular vote (Hug and Tsebelis, 2002; 
Hug, 2004). Latin America has not escaped this trend. Starting from the 1980s, IDD have been incorporated into most post-transitional Latin American constitutions, and over the past 25 years, the use of these tools in the region has increased remarkably. The issue has increasingly drawn scholarly attention in recent years and advocates of direct democracy have emphasised its potential to foster democratic participation and enhance the ability of citizens to exercise vertical control over their representatives (Mansbridge, 1983; Barber, 1984; Schmitter, 2000; Abromeit, 2004). However, the picture that emerges from an analysis of the Latin American experience with direct democracy is a different one; we find ourselves confronted with the apparent paradox that, despite its putative bottom-up potential, direct democracy has mainly remained a top-down affair in the region. This article seeks to answer two questions related to this phenomenon:

1. What motivates the incorporation of IDD into the representative structure of presidential regimes?

2. What consequences can be expected with regard to democratic accountability in the region?

For the past ten years, levels of support for democracy, satisfaction with democratic functioning and institutional trust have been declining in most Latin American countries. Opinion polls reveal a deficient connection between civil society and the state and a growing disjunction between politicians and their citizenry (UNDP, 2004). The democratic disenchantment of Latin American citizens can be attributed to a number of reasons such as the poor record of the newly established electoral regimes in combating poverty, as well as the persistence of clientelism and systematic corruption. However, the lack of efficient accountability mechanisms has been identified as one of the major obstacles to democratic consolidation in the region. Whereas in most advanced democracies parties in office stick to the policy priorities revealed in their manifestos; a phenomenon frequently observed in Latin America is that directly elected presidents govern virtually unconstrained, carrying out policies that bear little resemblance to the promises of their campaigns, thus ignoring the instructions inherent in their mandate (Stokes, 1997). The strategy of politicians to promise one thing during campaigns only to do something completely different once in office have contributed to the fact that two decades after transition from authoritarian rule, citizens fail to develop the confident attitude towards representative democracy that is essential for its consolidation.

According to O'Donnell, the unpredictability of governmental behaviour in Latin America's delegative democracies is rooted in the absence of horizontal accountability defined as:

the existence of state agencies that are legally enabled and empowered and factually willing and able to take actions that span from routine oversight to minimal sanctions or impeachment in relation to actions or omissions by other agents or agencies of the state that may be qualified as unlawful. (O’Donnell, 1999: 38)

From this perspective, the accountability deficit is ascribed to inefficient horizontal control and monitoring between independent state agencies. 
Despite the popularity of O'Donnell's concept among Latin America specialists, it is not uncontested. Scholars following the rational choice school of neo-institutionalism have conceptualised accountability as a model of retrospective voting. Citizens, as principals, have a criteria by which they set a standard of performance to evaluate governments, as their agents, and decide to sanction them if they fail to fulfil these criteria (Przeworski, Manin and Stokes, 1999). Different from parliamentary systems, presidential systems are peculiar in their establishment of multiple competing agents; executive and legislative branch are both constituted by direct election and thus not institutionally accountable to one another. Their separate origin and survival makes them direct agents of the voters. Given these parallel patterns of agency relations, presidential systems constitute a mix of vertical accountability and mutual horizontal control, which represents a particular challenge for constitutional designers. Opinions about how the lack of accountability should be addressed diverge. Whereas some authors suggest reforms of electoral rules in order to align incentives for legislators with the interests of the electorate (Shugart, Crisp and Moreno, 2000; Colomer and Negretto, 2005), Przeworski, Manin and Stokes (1999) consider electoral accountability mechanisms insufficient and advocate an extension of the traditional systems of checks and balances by the establishment of autonomous accountability agencies subject to direct popular control.

Although the main lines of debate reveal conflicting views about the most effective way to address the accountability deficit, there is broad consensus that the key to further consolidation in Latin America lies in institutional engineering. In this context, it is astonishing that, despite the proliferation of IDD in recent years, the question whether these tools are suitable institutional solutions to the accountability problem has received little attention. Several authors mention IDD parenthetically in connection with accountability problems (Przeworski, Manin and Stokes, 1999; Altman, 2002b), yet a systematic discussion about this relationship is still outstanding. The typology developed subsequently aims at closing this gap by distinguishing between the different IDD with respect to their aptitude to foster vertical accountability and mutual horizontal control in presidential systems.

\section{A Classification of IDD - Relevant Criteria of Distinction under Accountability Aspects}

Direct Democracy is a complex phenomenon consisting of various institutions that have different consequences with respect to the influence of actors in the process of political decision-making (Uleri, 1996; Setälä, 1999). As stated above, governments are accountable if the institutional structure provides the principal (i.e. the electorate) with a degree of political control that allows them to impose sanctions for irresponsive behaviour on the agents. ${ }^{1}$ As the literature on IDD developed over the years, two criteria

1 Stróm (2003) identifies three abilities of principals as salient forms of sanction: (a) block or amend decisions made by an agent; (b) de-authorise the agent; and (c) impose specific penalties. 
crystallised as central for the assessment of the influence of political actors in direct democratic processes (Smith, 1976; Suksi, 1993; Butler and Ranney, 1994; Uleri, 1996; Hug and Tsebelis, 2002; Altman, 2005):

1. Who may initiate the process?

2. Who is the author of the proposal appearing on the ballot?

\section{Mandatory Referendums}

First, we need to distinguish between referendums that are constitutionally required and those that are not. Constitutionally required referendums, commonly referred to as mandatory referendums, are triggered automatically, that is, they must be arranged in situations explicitly stipulated in the constitution (Suksi, 1993; Setälä, 1999). The question of who initiates the referendum becomes superfluous here because a promoting agent is not required and neither citizens nor representatives are able to set the agenda of a referendum (Uleri, 1996; Hug and Tsebelis, 2002). Mandatory referendums can thus be regarded as inbuilt mechanisms that ensure that the political actors who are normally in charge of the policy-making process will not be able to alter the legislative status quo against the will of the electorate (Jung, 2001; Hug and Tsebelis, 2002).

\section{Facultative Referendums}

Referendums that are not required by the constitution are referred to as facultative referendums. They are promoted at the request of an agent, who is constitutionally authorised to initiate the procedure to obtain a popular vote on a specific question (Uleri, 1996). The crucial criterion to distinguish between the different types of facultative referendums is the question of who is entitled to initiate the procedure. There are two general classes of facultative referendums: those initiated at the request of citizens and those initiated by elected representatives. In order to differentiate between them, I adopt Uleri's (1996) terminology denominating initiatives all non-mandatory popular votes promoted by an organised group of citizens, and referendums all non-mandatory votes promoted by either the executive or the legislative branch of government.

\section{Proactive and Reactive Types of IDD}

Let us now turn to the second distinction that needs to be made: who is the author of the legislative proposal appearing on the ballot? Does the initiator of a direct democratic process simultaneously act as the agenda setter by formulating the question, or are agenda setter and initiator different actors? Concerning government-initiated referendums, the question of whether initiator and author coincide has considerable consequences for mutual inter-branch control. Following Mainwaring and Shugart (1997), one way of analysing executive-legislative power relations in presidential systems is to examine the exercise of power with regard to the legislative status quo. Powers that allow one of the two branches to establish a new status quo are termed proactive, whereas those that simply allow them to defend the status quo are termed reactive. I 
adopt this terminology to distinguish between different types of IDD. The right to initiate a referendum process and ask any question, for example, equips a president with a powerful proactive instrument that can be used to circumvent a hostile majority in Congress and enlarge the legitimation basis for his or her preferred policies by submitting them directly to popular vote. On the other hand, if Congress has the possibility to demand a referendum on a presidential bill, it disposes of a reactive instrument to limit excessive presidential power in the legislative process.

An analogous differentiation can be made with regard to initiatives. It has to be settled whether citizens' possibilities of exercising vertical political control are restricted to vetoing against legislative proposals made by their representatives or if they may present proposals themselves. In both cases, the citizenship has the right to trigger the process. However, there is an important difference. If an initiative can merely deal with a decision made by a governmental body, the role of the citizens is reactive, they are allowed to react to politicians' attempts to effect policy changes (Gamble, 1997; Jung, 2001). If, on the other hand, citizens themselves can formulate a ballot proposal themselves, they can actively challenge the status quo and put issues on the political agenda. Combining the proposed criteria, we arrive at a fivefold basic typology of IDD (Breuer, 2007):

- The mandatory referendum: A popular vote that is automatically convoked in situations explicitly stipulated in the constitution.

- The proactive initiative: A procedure initiated by a stipulated number or percentage of voters, who sign a petition, asking that a proposal formulated by an organised group of citizens be put to popular vote.

- The reactive initiative: A procedure initiated by a stipulated number or percentage of voters, who sign a petition, asking for a proposal made by elected representatives to be put to popular vote.

- The proactive referendum: A procedure initiated by elected representatives, from either the legislative or executive branch, who request that a proposal formulated by themselves be submitted to popular vote.

- The reactive referendum: A procedure initiated by elected representatives, from either the legislative or executive branch, who request that a proposal formulated by the opposite branch be submitted to popular vote.

We can now proceed to establish further subtypes of these general types. A formal way to distinguish between the subtypes of reactive initiatives is to choose a temporal criterion, specifying the precise moment at which an IDD intervenes in the decisionmaking process. Abrogative initiatives are restricted to reverting laws, which have already been enforced. They function as a retrospective check on elected representatives, that is, vertical control can only be exercised at the end of a decision-making process. Rejective initiatives intervene at an earlier point of a decision-making process; citizens may use them to block passage of a pending bill. Concerning proactive initiatives, the distinction that needs to be made is whether the proposal submitted by the citizenship concerns ordinary legislation (popular initiative) or constitutional law (constitutional initiative). Both tools equip citizens with considerable agenda-setting powers because the impulse that actually starts a decision-making process originates from the citizenship. 
A final distinction concerning the subject matter needs to be made: the crucial question is whether a popular vote addresses an issue or on a person. The recall is designed to make representatives continuously responsible to voters. After the collection of a preset number or percentage of signatures, a popular vote is called in order to determine whether a representative should be removed from office prior to fulfilment of their term (Zimmerman, 1986; Altman, 2002a). The recall constitutes a retrospective check on elected officials and enables voters to sanction irresponsive behaviour beyond regular elections. Table 1 summarises the classification described above.

\section{Assessing the Accountability Potential of the Various Types of IDD}

We can now address the question of whether IDD are appropriate tools to induce vertical accountability and foster mutual horizontal control in the representative structures of presidential democracies. Theoretically, the mandatory referendum, the reactive referendum, as well as the various subtypes of initiatives are suitable to fulfil this function. Vertical accountability is strengthened by mandatory referendums and initiatives, although in different manners and at different stages of the political process. Mandatory referendums and rejective initiatives serve as legal impediments to prevent a policy change, which is opposed by a majority of the electorate, whereas abrogative initiatives and the recall introduce vertical control at a later stage, allowing voters to evaluate retrospectively whether the performance of their representatives complies with their preferences. In case of a negative assessment, they are enabled to apply sanctions by either reversing unwanted policies or removing irresponsive officials from office.

Popular initiatives and constitutional initiatives are instruments that are best described as substitutive to representative democracy. They enable citizens to adopt the role of legislators and introduce issues into the political agenda - even against the will of their elected representatives. They therefore clash with the standard view according to which accountability mechanisms operate on the basis of ex-post control, which principals exercise over their agents (Przeworski, Manin and Stokes, 1999; Strom, 2003) and are particularly strong tools of vertical control, which provide the electorate with considerable agenda-setting powers.

Referendums initiated by elected representatives affect the vertical and horizontal axes of accountability in a complex manner. Concerning vertical accountability, Hug and Tsebelis (2002) and Hug (2004) have proven mathematically that constitutional provisions for referendums shift policies towards the preference of the median voter. Hug and Tsebelis argue that the mere existence of referendum devices suffices to produce this change in legislative outcomes since strategically thinking actors will anticipate that any change of the legislative quo, which moves policies away from the median voter's preferences, can immediately be defeated by a referendum, and will thus care to make proposals that are located inside the set of preferences of the median voter.

Concerning the horizontal axis of accountability, mutual inter-branch control is strengthened by the reactive referendum; it increases the chances of members of the executive and legislative to check on the opposite branch of government. It can thus be used to defuse tensions resulting from the dual legitimation problem of presidential 
Direct Democracy and Accountability

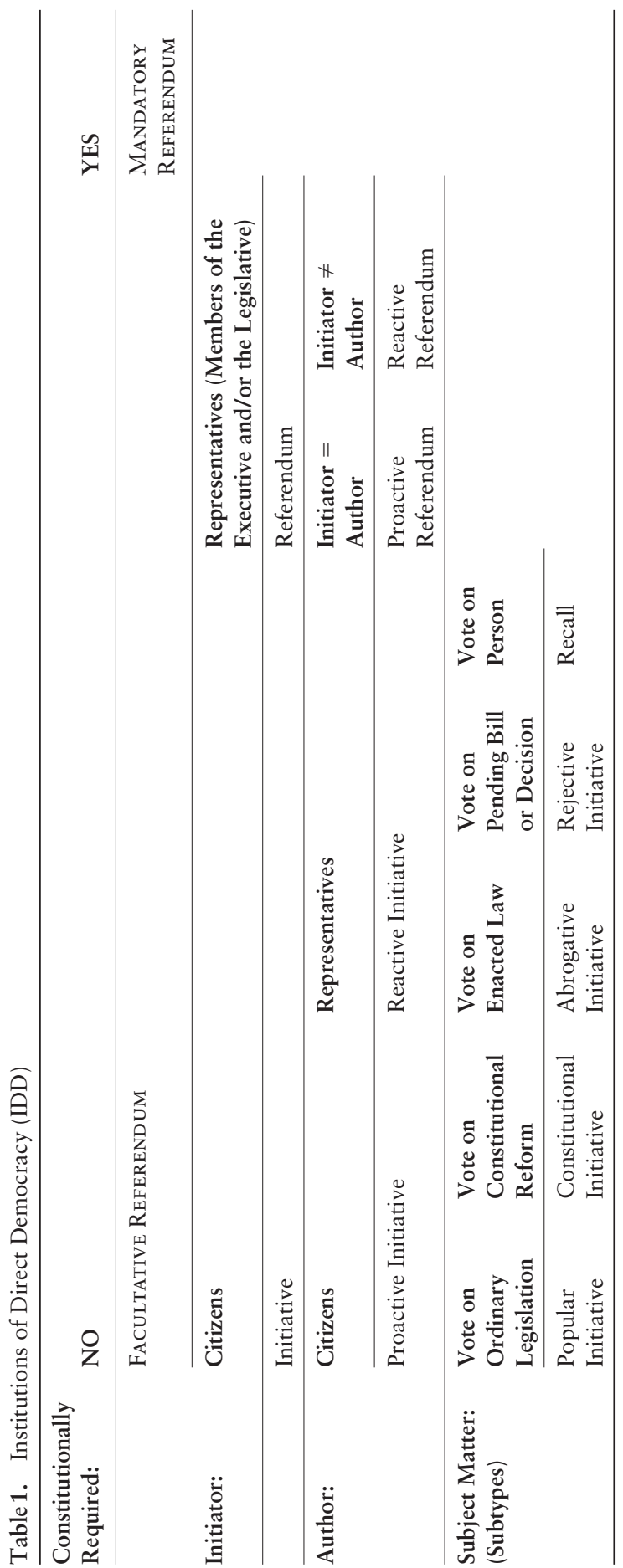


systems formulated by Juan Linz: 'when a majority of the legislature represents a political option opposed to the one the president represents [...] who has the stronger claim to speak on behalf of the people: the president, or the legislative majority that opposes his policies?' (Linz, 1990: 53). A reactive referendum offers a straightforward answer to Linz's question: let the people decide!

The proactive referendum, on the other hand, runs counter to the concept of horizontal accountability because it increases the chances to defy control by the opposite branch and renders a unilateral change of the legal status quo possible. Alarmingly, as will be shown in the following sections, it has been the use of precisely the latter tool that has dominated direct democratic practice in Latin America so far. While rhetoric appeal to the theoretical accountability potential of IDD has been made in order to justify the implementation of this instrument, in practice, authoritarian-minded, neopopulist presidents have repeatedly sought to ride roughshod over legislatures and go round parliamentary deliberation by making use of proactive referendums.

\section{Constitutional Provisions for IDD and Experience with Direct Democracy in Latin America 1978-2004}

Fifteen out of the eighteen Latin American presidential democracies present constitutional provisions for the use of instruments of direct democracy on a national level. ${ }^{2}$

References to mandatory referendums appear in seven constitutions. Among them, six explicitly refer to required referendums for constitutional changes. However, in only four cases (Guatemala, Paraguay, Uruguay and Venezuela) is a ratification of any constitutional amendment by popular vote obligatory, whereas in Panama and Peru the mandatory procedure is related to specific problems in the legislative process regulating constitutional reforms. Provisions for facultative referendums have been included in thirteen constitutions, procedures initiated 'from above' being the dominant type. Whereas all countries with provisions for facultative referendums allow for government-initiated procedures, only eight constitutions (Bolivia, Colombia, Costa Rica, Ecuador, Nicaragua, Peru, Uruguay and Venezuela) allow for the use of citizentriggered initiatives. In Argentina, Brazil, Ecuador, Paraguay, Uruguay and Venezuela, the right to trigger a referendum is reserved for Congress, whereas in Bolivia, Costa Rica, Guatemala, Nicaragua, Peru and Venezuela, both branches may act as an initiating authority. Only in Ecuador is the initiation of a referendum an exclusively presidential asset. Provisions for reactive referendums explicitly exist in Chile, Colombia, Paraguay and Venezuela.

Between 1978 and 2004, 34 popular consultations have been held in eleven countries. The dominance of the referendum type initiated 'from above' observed in the constitutional analysis is confirmed in the region's practical experience with direct

2 For each of these countries I consulted the most recent constitution. Table 2 displays provisions for instruments of direct democracy in these countries according to the classification presented in Table 1 . 
democracy, as can be seen from Figure 1. Although several countries dispose of advanced provisions for citizen initiatives, the practical use of IDD has mainly been limited to the referendum type initiated by either the legislative or the executive branch of government. At the same time, legislatures have played a rather limited role in direct democratic processes and have been far from fully exhausting the accountability

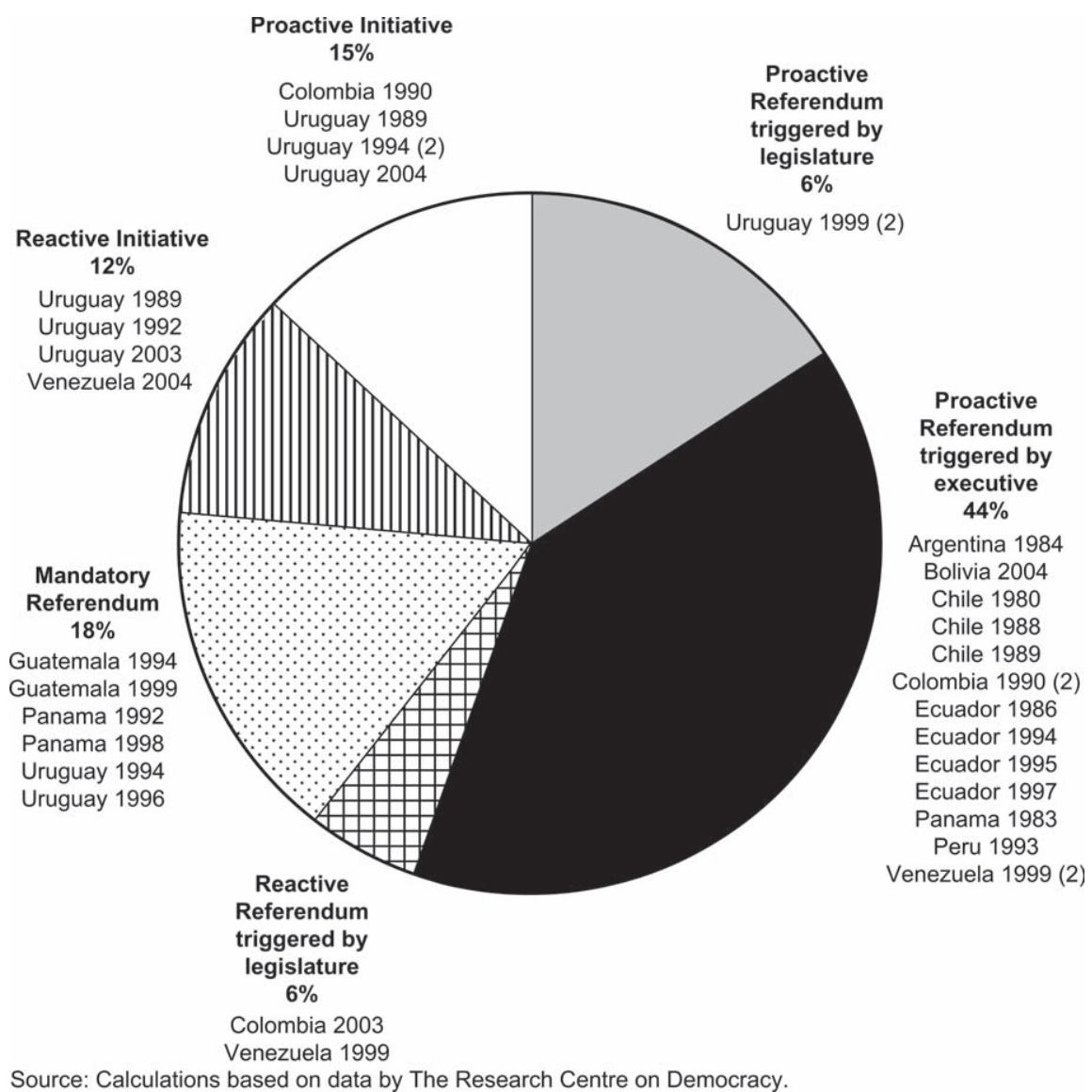

Figure 1. Occurrence of IDD in Latin America by Type, 1978-2004

Source: Corte Nacional Electoral de Bolivia

3 This figure is based on the data-set elaborated by the C2D - Research and Documentation Centre on Direct Democracy, Geneva. It has to be noted, that the beginning of the 'third wave of democratisation', which Huntington set for the year 1978, was chosen as the temporal criterion for case selection. For this reason, the figure also contains several direct democratic events, which occurred prior to democratic transition in the respective countries. Another criterion is the constitutionality of the process. Extra-constitutional referendums were not included, with the exception of the Colombian constitutional initiative in 1990, whose result was subsequently declared binding by the Constitutional Court. Referendums, which consisted of several questions, have been counted as one single event. 
Anita Breuer

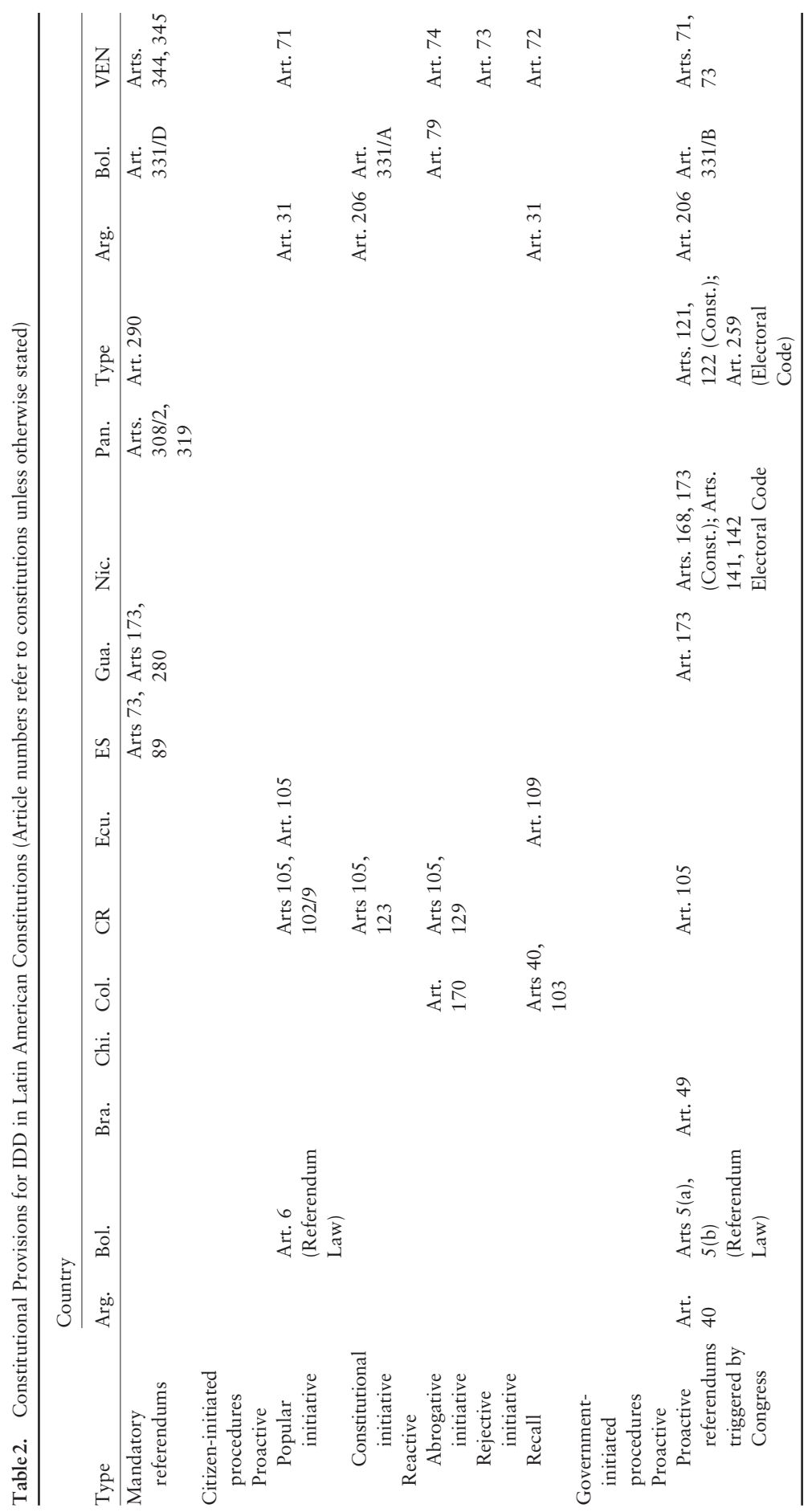


Direct Democracy and Accountability

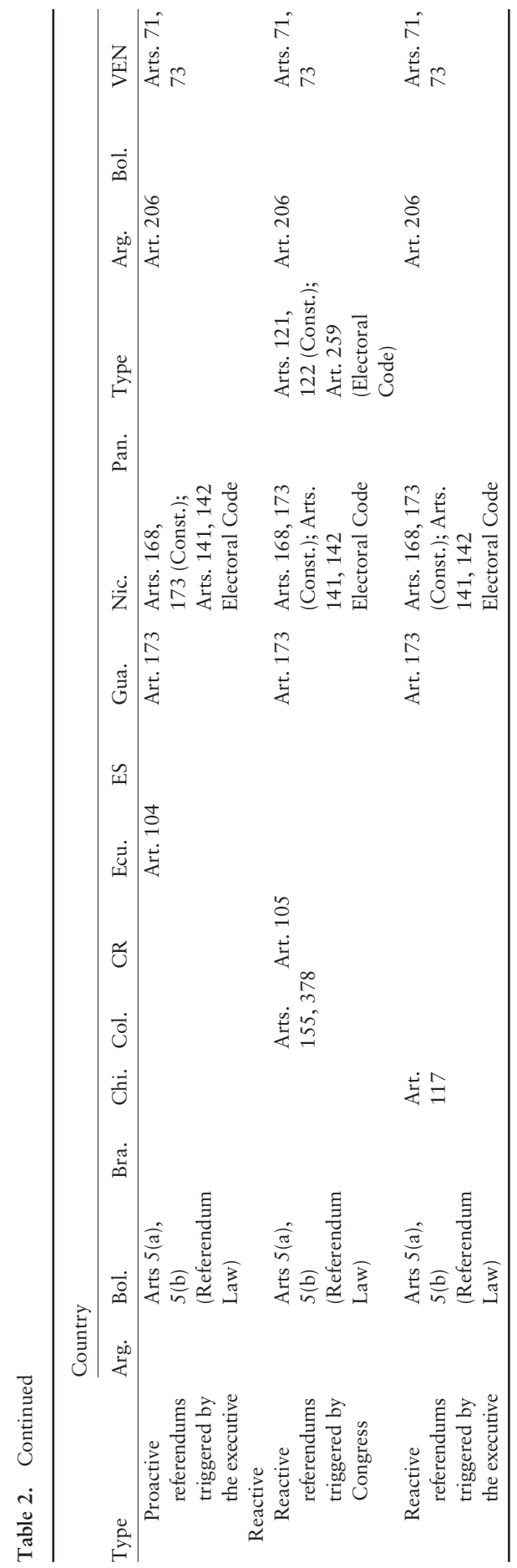


potential inherent in their countries' constitutions. Only on two occasions did legislatures make use of a reactive referendum on a government decision (Venezuela in 2000 and Colombia in 2003). However, it has to be noted that only the latter presents a genuine instance of the legislature exercising control over the executive, because the Venezuelan referendum on suspending leaders of the National Trade Union Confederation was called for by a clearly Chávez-dominated Congress. With 44 per cent, the executive-triggered proactive referendum accounts for the majority of direct democratic events in the region so far. On several occasions, politically isolated heads of the executive have tried to employ this tool in order to circumvent oppositional majorities in Congress or stabilise their position in a crisis. In such contexts, referendums have been used to broaden the legitimation basis used by presidents rather than as a means of obtaining a popular vote on a specific political decision.

In 1995, for example, the Ecuadorian President Durán Ballén, tried to strengthen the mandate of his crisis-ridden administration by means of a referendum. His centre-right minority government faced a strong leftist opposition. Moreover, his vice-president, Alberto Dahik, became the protagonist of a corruption scandal and was on trial before the Supreme Court for misappropriation of eight million dollars. On emission of an arrest warrant, Dahik fled in a private plane to Costa Rica. At the bottom point of his popularity, Durán Ballén tried to bolster his public image and regain the political initiative by means of an ambitious constitutional reform project that intended to strengthen the president's power vis-à-vis the ungovernable Congress. The most contentious issue was the proposal to concede the President the right to dissolve the Congress, which was widely perceived as an attempt to install a constitutional dictatorship. However, the attempt failed and the proposal was rejected by the electorate in the referendum vote.

Certainly the most glaring instance of contempt of democratic institutions and populist misuse of this tool was the referendum convoked in 1993 by Alberto Fujimori in Peru. In 1990, Fujimori gained the presidency with a highly personalistic campaign detached from traditional parties. Once in office, he formed a cabinet composed of technocrats and drew up a government programme that aimed to combat the country's hyperinflation. During his first year in office, he continuously attacked the inefficiency of Peru's political institutions and increasingly relied on a small group of personal advisers and military officers (Cotler, 1995). As the legislative-executive conflict grew more acute in April 1992, Fujimori dissolved the Congress by decree and ordered the army to take over the congressional palace, claiming that the legislature was deeply corrupt and obstructed the process of economic reform. International pressures and the need to legitimate his regime led Fujimori to agree to the convocation of a 'Constituent Congress' commissioned with the task of writing a new constitution. The new charter borrowed elements from the strong presidencies of East Asian authoritarian systems, which Fujimori regarded as development models for Peru. Besides extending the presidential term to five years, it allowed the incumbent to run for re-election, gave him or her authority to make military promotions and replaced the two-chamber Congress with a smaller one-chamber legislature. The referendum, which was approved by a narrow 52.33 per cent of the electorate, was widely regarded as a 'plebiscite' on Fujimori's leadership and a strategy to legitimise the autogolpe, which constituted his government's 'original sin'. 


\section{IDD and Constitutional Reform: The Case of Bolivia}

The examples referred to above, as well as the dominance of government-initiated referendums in constitutional frameworks, suggest that the decision of Latin American governments to resort to referendums is mainly rooted in specific problems in executivelegislative interaction and may be additionally spurred by contextual factors such as the government's need for rehabilitation, whether because of preceding corruption scandals or a lack of democratic legitimation.

In fact, it seems naïve to assume that referendums exclusively serve genuine consultative purposes or are promoted by governments on the grounds of a participatory understanding of democracy. One has to bear in mind that members of constituent assemblies are often legislators facing the possibility of re-election. It is thus more reasonable to assume that such reforms result from processes of strategic interaction between actors with diverging preferences. Their preferences concerning constitutional design will not necessarily depend on the potential of the different institutional options to enhance social utility, but rather on their potential of maximising these actors' capacity to achieve policy outcomes they prefer (Horowitz, 2002). In the following section, a detailed account of the evolution of the Bolivian law on referendums passed in 2004 illustrates such a process of strategic interaction and sheds some light on the motivations of political actors to resort to such tools.

\section{Social Background: Regional Antagonisms and Ethnic Conflict}

Bolivian society is divided along two major conflict lines: ethnicity and geography. The republic has two distinct regions: the high Andean plateau and the eastern and southern lowlands. Quechua and Aymara are the two predominant indigenous population groups in highland regions, while lowland Bolivia is principally mestizo. The lowlands have a diverse economy, mainly based on oil and gas production. Being a typically Latin American centralist state, in the past, Bolivian politics tended to revolve around the capital, La Paz. As the population and the economy in the lowlands grew (especially in the prosperous capitals of Santa Cruz and Tarija), traditional regional antagonisms gained new relevance in public discourse and members of the business elite, in this part of the republic, increasingly perceived the export of natural resources by private companies as the key to greater autonomy from La Paz, with some even favouring secession from the republic (St John, 2004; Centellas, 2005).

The setting in the Altiplano is quite a different one; mining has traditionally been the basic industry in the highlands. After the Movimiento Nacionalista Revolucionario (MNR) seized power in the revolution of 1952, the mines were re-nationalised and the new government supported indigenous efforts to forcibly recuperate communal lands (Van Cott, 2000). However, national control over metal resources soon faded again when lack of capital to modernise production methods forced successive governments to contract services with foreign companies for their extraction, thus setting the stage for perpetual conflict with the miners' unions. Meanwhile, the limits of traditional agriculture on family-sized parcels induced indigenous migration into the cities and 
forced the campesinos of the Altiplano to engage in the alternative cultivation of coca. The decision of the Bolivian government to support the US State Department in its 'war on drugs' imposed additional economic hardship in the region and fuelled social unrest. One of the consequences was the rise of the coca growers' trade union, its leader, Evo Morales, and the associated political party Movimiento al Socialismo (MAS). Given that the benefits of metal exportation did not trickle down to their long marginalised region, its inhabitants doubt that they will benefit from the expected natural gas revenue.

\section{Institutional Background: Executive-Legislative Relations in a 'Double Hybrid' System}

Despite this difficult social setting, Bolivia's transition to democracy in 1982 was followed by almost two decades of regime stability, which raised confidence about the prospects of democratic consolidation (Linz and Valenzuela, 1994; Whitehead, 2001). Scholarly optimism was mainly based on two institutional variables that structure executive-legislation relations in Bolivia: hybrid presidentialism and the introduction of a mixed-member proportional electoral system (MMP).

The key component to Bolivia's model of 'parliamentarized presidentialism' (Gamarra, 1997) is encoded in Article 90 of the constitution: if no candidate obtains an absolute majority in the national elections, the president is elected in a congressional run-off amongst the two top contenders. Since this feature theoretically implies majority legislative support for the president, it has been regarded as an adequate approach to address one of the basic problems of democratic stability in Latin America's political systems: the risk of minority governments and legislative deadlock that stems from the difficult combination of presidential regimes with multiparty systems (Mainwaring, 1993). Nevertheless, critical voices argued that post-electoral bargaining to ensure legislative support was dominated by presidential patronage strategies rather than by programmatic compromises and thus fostered corruption and the detachment of the political class from the demands of its electorate (Gamarra, 1997; Falcoff, 2004).

In order to overcome this lack of responsiveness and accountability, in 1994, the traditional List Proportional Representation system was replaced by a MMP system combining first-past-the-post voting in single-seat districts with party list voting by PR on the national tier. Such combined systems have been commended by scholars for creating incentives for closer exchanges between voters and representatives from single-seat districts while simultaneously assuring fair party representation on the national level (Colomer and Negretto, 2005). Parallel to the reform of the electoral system, the first Sanchez de Lozada administration (1993-1997) implemented the Law of Popular Participation (LPP). In order to strengthen participation on the municipal level, the LPP created 311 autonomous local governments with direct elected municipal officials. There is evidence that these reforms, which mutually reinforced the principle of regionalised politics, were successful in establishing closer ties between political parties and the electorate, but at the same time encouraged party system fragmentation and polarisation by aggravating existent ethnic and regional cleavages (Centellas, 2005). 


\section{Party System Development, 1985-2002}

As in other deeply divided societies, Bolivia has been faced with the problem of extreme multipartism in the past. While between 1985 and 1993 post-electoral bargaining had produced a bipolar system centring around a block of the three systemic parties (MNR, MIR and ADN), in 1993, two populist parties, UCS and CONDEPA, which appealed directly to the urban indigenous population, entered the electoral arena. Partly because of the reforms described above, the party system fragmented further after the elections of 1997: several regional parties that had previously been excluded from representation, such as the FRI, the NFR and the IU (with Evo Morales as its principal candidate), managed to win district seats. The subsequent 2002 elections brought about the final breakdown of the old bipolar system. The vote share of the ADN dropped to 3.4 per cent, whereas the second place fell for the first time to a non-systemic party, the MAS, which obtained 20.94 per cent of the total vote. With this new regionalist dynamic injected into the electoral system, moderate coalition bargaining became extremely difficult. After a coalition including the MNR, MIR, ADN and UCS had been hastily stitched together, parliament chose the frontrunner, MNR's Sánchez de Lozada, in the congressional runoff.

\section{The Way to Constitutional Reform}

In 2003, President Sánchez de Lozada's backing for a five billion dollar plan for a foreign consortium to export natural gas to California led to increasingly violent antigovernment protests. At the peak of civil unrests in autumn 2003, which came to be known as the 'gas war', Sánchez de Lozada made a final attempt to stabilise his position and regain legitimacy by announcing a referendum on the use of the national resources of hydrocarbons. However, when his offer failed to contain popular mobilisation, he opted to quell the riots with the help of the military, causing the deaths of approximately 80 protestors. The broad coalition of relatively un-programmatic parties proved unable to cope with the crisis. The government finally collapsed when vice-president Mesa dropped his support for Sánchez de Lozada, citing differences in how the president was dealing with the unrest. Sánchez de Lozada was forced to resign and Mesa was sworn in by Congress in his stead. Shortly after taking office, Mesa introduced a bill into Congress proposing the passage of a law in order to facilitate the referendum announced by his predecessor.

After Sánchez de Lozada's demission, attempts to govern with majority parliamentary support continued to fail. Being a journalist without a previous party career, Mesa did not dispose of a power base within the MNR, which would have enabled him to forge an ad hoc alliance. Against this background, he opted for a strategy to sidestep Congress and develop the public image of a 'caretaker president' (Andean Group Report, 2003). Instead of reflecting party balance of power in Congress, the composition of his cabinet sought to pay tribute to the ethnic and regional cleavages that threatened democratic stability. The decision to form a government without parties was, in his words, "not an attempt to deny the essential importance of party institutions in a democracy, but an inescapable response to the fact that the parties have entered in a 
severe crisis, not only with the State, but above all with society' (Mesa Gisbert in La Razón, 20 September 2003).

Mesa's decision to initiate the reform process for the adoption of the referendum was catalysed by several factors. ${ }^{4}$ The most pressing one was the political legacy. Sánchez de Lozada's announcement to submit the controversial hydrocarbons issue to referendum had raised popular expectations that Mesa could not afford to ignore if he wanted to prevent further escalation of the situation. Another crucial factor was his lack of a direct popular mandate. Although his assumption of office complied with constitutional regulations, he had not been elected directly and needed to distance himself from his unpopular predecessor. Public opinion polls delivered good prospects of turning the referendum into a vote of confidence on his person. In a survey released in November, Mesa achieved extraordinarily high approval ratings of 82 per cent, whereas his key opponent, Morales, attracted only 33 per cent of the respondents' preferences (Apoyo, Opinión y Mercado Bolivia, 2003).

Mesa's lack of a stable support basis made it difficult to implement energy policies of his preference by going down the ordinary route in Congress. Congressional opposition to his project came from two directions: whereas legislators from the oil-producing departments Santa Cruz and Tarija favoured maintenance of the status quo, the MAS's blueprint for a new hydrocarbons law was based on the principle of re-nationalisation of the companies privatised under Sánchez de Lozada's administration. Meanwhile, Mesa's own preferences were shaped by the challenge of mediating between the demands of an impoverished electorate and the requirements to keep international lending organisations on board. He was thus more inclined to win over the gas industry's critics by postulating tax increases on foreign companies operating in Bolivia.

\section{The Agenda of the Constitutional Reform Process}

The opportunity for the institutionalisation of the referendum presented itself when a constitutional reform package, presented by Mesa, was approved by majorities in both houses of Congress in February 2004. A key component of this package was the amendment of article 4, which previously confined popular deliberation to the three powers of the state and now extended this faculty to a constituent assembly, citizens' legislative initiatives and the referendum. In March 2004, a parliamentary commission consisting of members from all parties with congressional representation took up work on the development of a legislative framework for the implementation of the referendum. The commission elaborated several draft versions, altering considerably the original proposal made by Mesa. ${ }^{5}$ The final version of the Ley del Referéndum was debated and approved by Congress in June 2004.

A major criticism raised against the original executive bill was that it sought to establish a law for the exclusive regulation of a referendum on the contentious gas issue. The commission argued that a procedure requiring the sanctioning of any required referendum by a specific law was insufficient because it would obstruct the adequate use

4 Personal communication with Dr Luis Verdesoto (ILDIS).

5 Anteproyecto de Ley del Referéndum, Presidential Note PL-669/2003-2004. 
of this tool in the future, and that the development of a proper legislative framework regulating the implementation of the referendum would be necessary. One of the first steps was the development of a classification differentiating referendum types based on the criterion of initiation authority (Verdesoto, 2004). In the realm of government-initiated referendums, initiation authority was conceded to both the executive and the legislative power, the latter requiring a two-thirds majority of the Congress members present for passage. In the realm of citizen-initiated mechanisms, the only tool included was the popular initiative. As a concession to regional interests, the commission decided to include provisions for referendums and initiatives at the departmental as well as at the municipal level.

Another major concern was the potential for populist-manipulative misuse inherent in direct democratic instruments. In order to reduce this risk, the commission decided to introduce thematic restrictions and regulations concerning frequency of use, which had been absent in the original executive proposal. Furthermore, it prescribed the binding character of referendum results as well as judiciary control over the process. Finally, the National Electoral Court was given the exclusive right to carry out information campaigns, while private or partisan propaganda campaigns on referendum issues were prohibited.

\section{Developments in the Aftermath of the Referendum}

On 18 July 2004, President Mesa convoked a referendum in accordance with article $5 \mathrm{a}$ of the new referendum law, consisting of five questions (see Figure 2).

The result of the referendum - presenting approval rates of up to 92 per cent on the national level - was widely regarded as a solid vote of confidence in Mesa (see Table 3). Nevertheless, what seemed to be a resounding victory over his opponents would prove to stand on shaky ground. The Bolivian trade union federation (COB) and the confederation of peasants' union (CSUTCB) headed by Felipe Quispe had campaigned heavily among their members to boycott the referendum, arguing that Mesa had ruled out the key demand of the 2003 'gas war': the option of completely nationalising the country's gas resources. In the end, 60.07 per cent of Bolivians registered in the national electoral roll stayed at home on polling day (Corte Nacional Electoral, 2004). The principal difficulty, however, consisted in a consensual interpretation of the referendum's result and its transformation into legislation. The fifth question concerning the level of oil tax had been included in the questionnaire as a concession to demands made by the MAS in previous negotiations with Mesa's government (World Market Analysis, 2003) and its vague formulation made a translation of the 'public will' into a clear-cut instruction impossible. Obviously Mesa had opted deliberately for an equivocal formulation of the question - proposing a tax level of 'up to 50 per cent' - assuming that the referendum result would provide him with a mandate to unilaterally tailor the national energy policy. However, this would turn out to be a strategic mistake. His legislation proposal, which consisted in leaving oil royalties untouched at 18 per cent and slapping a 32 per cent tax on new exploitation contracts with foreign companies, left him with two sets of opponents: one, with the MAS and CSUTCB at the forefront, which pressed for the straight 50 per cent royalty rate they considered endorsed by the referendum, and the other, led by the business elites of the lowlands, threatening to unilaterally adopt autonomous governments (Latin 


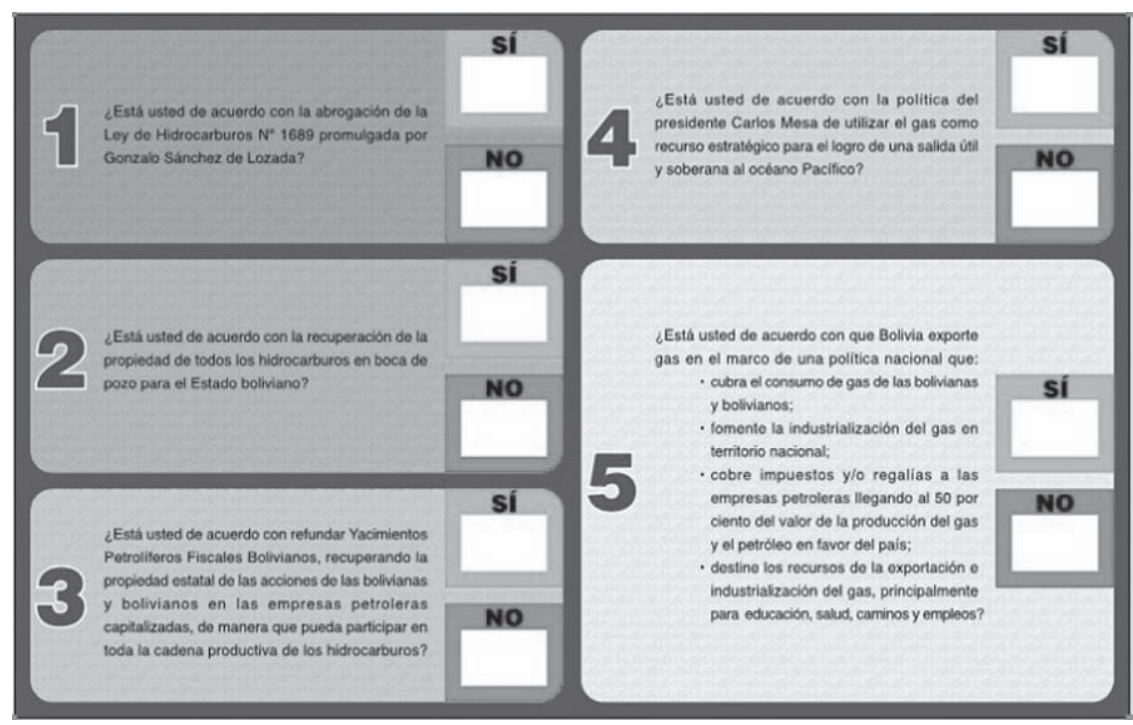

Figure 2. Ballot Proposal of the Bolivian Hydrocarbons Referendum 2004

Source: Corte Nacional Electoral de Bolivia.

1. Do you agree to the abrogation of the Law on Hydrocarbons No. 1689 promulgated by Gonzalo Sánchez de Lozada?

2. Do you agree to the repatriation of all of property of hydrocarbons at the wellhead?

3. Do you agree to the re-foundation of YPFB [the state owned oil and gas company privatised under Sánchez de Lozada] by restoring state ownership of the Bolivian people's stakes in capitalised oil companies, so that it can participate in the entire chain of production of hydrocarbons?

4. Do you agree with President Mesa's policy of using the national gas policy as a strategic recourse to achieve a viable and sovereign route of access to the Pacific Ocean?

5. Do you agree that Bolivia should export of gas as part of a national framework that

- covers the gas consumption of the Bolivian people;

- encourages the industrialisation of gas inside the nation's territory;

- levies taxes and/or royalties on oil companies of up to 50 per cent of the production value of oil and gas on for the nation's benefit;

- employs revenues from the export and industrialisation of gas mainly for education, health, roads, and employment.

American Weekly Report, 2005). In May 2005, Mesa's proposal obtained approval in the chamber of deputies with a narrow majority of 59 votes against 48 , but prompted fierce opposition from MAS and CSUTCB, who threatened to organise roadblocks if Mesa should refuse to prevent the passage of the law by vetoing his own bill. However, Mesa chose to let the objection term pass without taking action and the law was promulgated by Congress. As the wave of protest mounted to the extent of the 2003 gas war, Mesa announced his resignation in June 2005 in a nationally televised address, explaining that the civil unrests had made the country ungovernable. In an extraordinary session, legislators accepted his resignation and swore in the Chief Justice of the Supreme Court, Eduardo Rodriguez Veltze, as his successor.

Although the inauguration of Rodriguez was welcomed by protestors, who saw him as one of the few national figures not involved in previous political troubles, he made it clear from the start that he was not interested in completing his term but rather 
Direct Democracy and Accountability

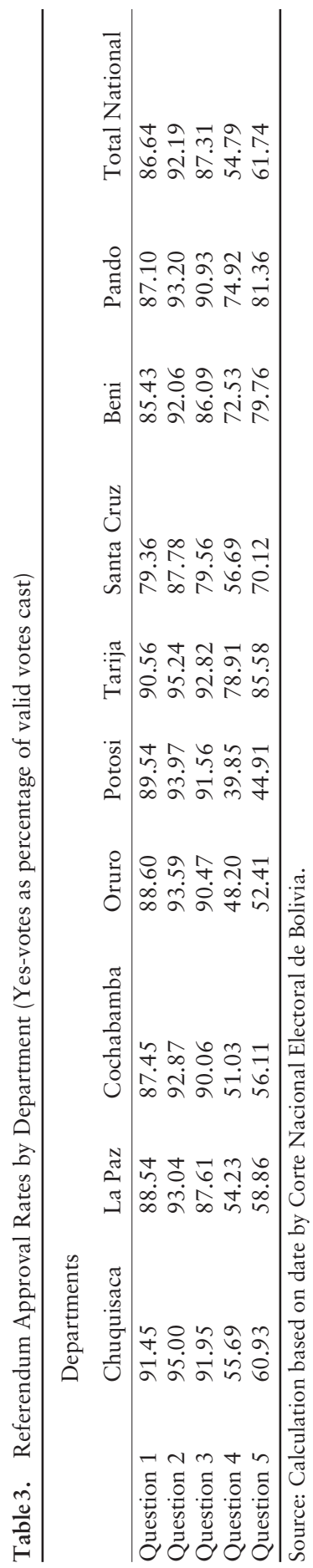


in setting the stage for early elections. In July 2005, Congress approved several constitutional changes that allowed early general elections for the President and Vice-president as well as all 157 members of Congress. The elections held on 18 December 2005 produced a landslide victory for Evo Morales and the MAS. With 53.7 per cent of the national vote, Morales became the first directly elected president since the country's democratic restoration in 1982, while the MAS captured a majority of 72 of the 130 seats in the Chamber of Deputies and twelve in the Senate. For a country as deeply divided as Bolivia, the election result was surprisingly united. Even in the secession inclined provinces of Tarija and Santa Cruz, the MAS did much better than pre-election polls suggested, winning vote shares of 43 and 33 per cent respectively (Corte Nacional Electoral, 2004). Apparently, not only the indigenous voters, but also a considerable part of the mestizo electorate calculated that handing Morales and the MAS a decisive victory would make Bolivia more governable, thus conferring on the new president and Congress a legitimacy their predecessors lacked (The Economist, 2006).

\section{Conclusions}

The case of Bolivia represents an instructive example, which may help to shed some light on two central questions posed at the beginning of this article:

1. What motivates the incorporation of IDD into the representative structure of presidential regimes?

2. What consequences can be expected with regard to democratic accountability in the region?

The evaluation of the Bolivian experience reveals two variables whose influence dominated the process of constitutional reform. Whereas the first is clearly of institutional character, the second is related to the specific political constellation. President Mesa's decision to initiate the reform process that led to the institutionalisation and application of the referendum took place under the institutional constraints that have long been identified as critical for the stability of multiparty presidential democracies. In highly fragmented party systems, probabilities are high that a president who lacks secure support in the legislature will find themselves in a situation where they are unable to accomplish their policy agenda by working through ordinary congressional proceedings (Mainwaring, 1993). Under such conditions, the use of a proactive referendum may appear as an attractive option to an isolated head of government to shortcircuit congressional opposition and push through policies by appealing directly to the electorate. The Bolivian experience suggests the interpretation that the adoption of these devices can be regarded as a logical consequence of the difficult institutional combination of presidentialism and multipartism. This finding also corresponds to the case of the Ecuadorian referendum under Durán Ballén described earlier.

Concerning the specific political constellations that increased the likelihood of an actual occurrence of a referendum in the Bolivian case, the decision to solve the conflict on the national energy policy via popular consultation was undoubtedly spurred by the high level of mobilisation of traditionally marginalised indigenous interests as well 
as Mesa's need to make up for his missing direct democratic legitimation as a transition president appointed by Congress. Here, the Bolivian case displays parallels to the Peruvian case in which Fujimori resorted to a referendum in order to make up for the lack of democratic legitimation of his government.

Similar to the Ecuadorian and Peruvian experience, the Bolivian case suggests that hopes about the possibility of enhancing democratic accountability by supplementing representative structures with elements of direct democracy should not be raised too high; a unilateral top-down instrument such as the proactive referendum is an ill-suited instrument to enhance mutual horizontal control, resolve conflict between state functions, and obtain the (re-)legitimation of authorities or positions. The ideal is of vertical accountability served as a rhetorical and ideological justification for the incorporation of the referendum into the constitution but this was virtually absent in this case when it came to the practical application. Consequently, one of the first measures taken by Morales on his assumption of office in 2006 was to issue a decree that reversed Mesa's hydrocarbons law and set the oil tax level at 82 per cent, thus adjusting the national energy policy to 'the sovereign people's unequivocal decision' expressed in the 2004 referendum (Decreto Supremo No. 28701).

According to all the signs, the newly adopted direct democratic institutions will continue to play an important role in policy-making in Bolivia. Whether this will work to the benefit or detriment of the country's democratic stability remains to be seen. On 2 July 2006, the country went to the polls to elect the members of a constituent assembly that will rewrite the constitution, and to vote in a referendum on increasing autonomy for the country's nine departments. The result of the latter reflected once again the regional differences that divide the country, and its interpretation was highly conflictive. While the prosperous eastern departments of the country voted decisively for increased autonomy, the majority of voters in the western department rejected it. The National Electoral Court rejected the arguments of the pro-secessionists in the east of the country who claimed that the votes of each department had to be considered separately, and ruled that the referendum was a national process whose results have to be judged nationally, that is, there would be no further autonomy for any department. However, the final decision on this is up to the Constituent Assembly who will define the power of autonomous departments. As this article is being written, the Constituent Assembly's decision is still outstanding. It remains to be seen whether its members will proceed in a manner that avoids further aggravation of the country's regional and ethnical conflicts.

\section{Acknowledgements}

I am indebted to the Instituto Latinoamericano de Investigaciones Sociales (ILDIS) and Dr Luis Verdesoto for providing me with useful insight and documentation on the process of constitutional reform in Bolivia. An earlier version of this article was presented at the workshop 'Political Participation and Collective Action: Tensions and Synergies Between Direct Democracy and Representative Democracy in Latin America' at the 7th National Congress of Political Science of the Argentine Society of Political Analysis (SAAP), Córdoba, Argentina, 15-18 November, 2005. I would like to thank participants at this venue for their helpful comments. 


\section{References}

Abromeit, H. (2004) 'Die messbarkeit von Demokratie: zur relevanz des kontexts'. Politische Vierteljahresschrift 45: 73-93.

Altman, D. (2002a) 'Popular Initiatives in Uruguay: Confidence Votes on Government or Political Loyalties?' Electoral Studies 21: 617-630.

Altman, D. (2002b) 'Prospects for E-Government in Latin America: Satisfaction with Democracy, Social Accountability, and Direct Democracy'. International Review of Public Administration 7: 5-20.

Altman, D. (2005) Democracia en el continente americano: Autolegitimacion gubernamental censura ciudadana? Politica y gobierno 7(2): 203-232.

Andean Group Report (2003) 'Goni goes, Mesa faces massive task'. 4 November.

Apoyo, Opinión y Mercado Bolivia (2003) 'Resumen de encuestas a la opinión pública'. Opinión data 3(10).

Barber, B. (1984) Strong Democracy: Participatory Politics for a New Age. University of California Press: Berkeley.

Breuer, A. (2007) Institutions of Direct Democracy and Accountability in Latin America's Presidential Democracies. Democratization 14(4): 554-579.

Butler, D. and Ranney, A. (1994) Referendums around the World. Macmillan: Washington.

Centellas, M. (2005) Mixed-Member Proportional Electoral Systems in New Democracies: The Bolivian Experience. Paper presented at the Annual Meeting of the Midwest Political Science Association, Chicago, 7-10 April.

Colomer, J. M. and Negretto, G. L. (2005) 'Can Presidentialism Work Like Parliamentarism?’ Government and Opposition 40: 60-89.

Corte Nacional Electoral (2004) Resultados referéndum 2004 [WWW document]. URL http://www.cne.org.bo [accessed 26 July 2007].

Cotler, J. (1995) 'Political Parties and the Problems of Democratic Consolidation in Peru', in S. Mainwaring and T. R. Scully (eds) Building Democratic Institutions. Party Systems in Latin America. Stanford University Press: Stanford, 323-353.

Decreto Supremo No. 28701 (2004) Gaceta Oficial de Bolivia [WWW document]. URL http://www.presidencia.gov.bo/gaceta/index.htm [accessed 26 July 2007].

Falcoff, M. (2004) The Last Days of Bolivia? American Enterprise Institute for Public Policy Research [WWW document]. URL http://www.aei.org/include/pub_print. asp?pubID=20580 [accessed 26 July 2007].

Gamarra, E. (1997) 'Hybrid Presidentialism and Democratization: The Case of Bolivia', in S. Mainwaring and M. Shugart (eds) Presidentialism and Democracy in Latin America. Cambridge University Press: Cambridge, 363-394.

Gamble, B. S. (1997) 'Putting Civil Rights to a Popular Vote'. American Journal of Political Science 41: 245-269.

Hug, S. and Tsebelis, G. (2002) 'Veto Players and Referendums around the World'. Journal of Theoretical Politics 16: 321-356.

Hug, S. (2004) Occurrence and Policy Consequences of Referendums: A Theoretical Model and Empirical Evidence. Journal of Theoretical Politics 16(3): 321-356.

Horowitz, D. L. (2002) Constitutional Design: Proposals Versus Processes. In A. Reynolds (ed.), The Architecture of Democracy. Constitutional Design, Conflict Management, and Democracy. Oxford: Oxford University Press, 15-36.

Jung, S. (2001) Die logik direkter Demokratie. Westdeutscher Verlag: Wiesbaden.

La Razón (2003) 'El presidente forma un gabinete a la medida de la crisis política'. 20 October.

Latin American Weekly Report (2005) 'Mesa rebuffed again but Morales also loses', 21 March.

Linz, J. (1990) The Perils of Presidentialism. Journal of Democracy 1(1): 51-69. 
Linz, J. and Valenzuela, A. (eds) (1994) The Failure of Presidential Democracy. John Hopkins University Press: Baltimore.

Mainwaring, S. (1993) 'Presidentialism, Mutipartism, and Democracy. The Difficult Combination'. Comparative Political Studies 26: 198-228.

Mainwaring, S. and Shugart, M. (1997) 'Presidentialism and Democracy in Latin America: Rethinking the Terms of the Debate', in S. Mainwaring and M. Shugart (eds.) Presidentialism and Democracy in Latin America. Cambridge University Press: Cambridge, 12-53.

Mansbridge, J. (1983) Beyond Adversary Democracy. University of Chicago Press: Chicago.

O'Donnell, G. (1999) 'Horizontal Accountability in New Democracies', in A. Schedler, L. Diamond, and M. F. Plattner (eds) The Self Restraining State: Power and Accountability in New Democracies. Lynne Rienner: Boulder, 29-52.

Przeworski, A., Manin, B. and Stokes, S. (1999) 'Elections and Representation', in A. Przeworski, B. Manin, and S. Stokes (eds) Democracy, Accountability and Representation. Cambridge University Press: Cambridge, 29-54.

Schmitter, P. (2000) How to Democratize the Euro-Polity and Why Bother. Rowman and Littlefield: New York.

Setälä, M. (1999) 'Referendums in Western Europe - A Wave of Direct Democracy?' Scandinavian Political Studies 22: 327-340.

Shugart, M., Moreno, E. and Crisp, B. (2000) The Accountability Deficit in Latin America. Paper presented at Institutions, Accountability, and Democratic Governance in Latin America in Kellog Institute for International Studies, University of Notre Dame, Indiana May 8-9, 2000.

Smith, G. (1976) 'The Functional Properties of the Referendum'. European Journal of Political Research 4: 1-23.

St John, R. B. (2004) Bolivia's Referendum about More than Gas. FPIF (Foreign Policy in Focus) [WWW document]. URL http://www.irc-online.org/fpif/fpiftxt/1090 [accessed 26 July 2007].

Stokes, S. (1997) 'Democratic Accountability and Policy Change. Economic Policy in Fujimori's Peru'. Comparative Politics 29: 209-227.

Strom, K. (2003) Parliamentary Democracy and Delegation. In K. Strom, W. Müller and T. Bergman (eds) Delegation and Accountability in Parliamentary Democracies. New York: Oxford University Press, 55-108.

Suksi, M. (1993) Bringing in the People - A Comparison of Constitutional Forms and Practices of the Referendum. Dordrecht: Martinus Nijhof.

The Economist (2004) 'From Here to 2007 without Falling?', 24 January.

The Economist (2006) 'Enter the Man in the Stripey Jumper; Bolivia', 21 January.

Uleri, P. V. (1996) 'Introduction', in M. Gallagher and P. V. Uleri (eds) The Referendum Experience in Europe. Macmillan: London, 1-19.

UNDP (2004) Human Development Report 2004: Bolivia [WWW document]. URL http:// hdr.undp.org/hdr2006/statistics/countries/country_fact_sheets/cty_fs_BOL.html [accessed 26 July 2007].

Van Cott, D. L. (2000) 'Party System Development and Indigenous Populations in Latin America: The Bolivian Case'. Party Politics 6: 155-174.

Verdesoto, L. (2004) El proceso constituyente en Bolivia. A horcajadas entre la Nación y sus partes. ILDIS: La Paz.

Whitehead, L. (2001) 'The Viability of Democracy', in L. Whitehead and J. Crabtree (eds.) Towards Democratic Viability: The Bolivian Experience. Palgrave Mac Millan: Oxford, 3-20.

Zimmerman, J. F. (1986) Participatory Democracy: Populism Revived. New York: Praeger.

Zovatto Garetto, D. (2002) 'Las instituciones de democracia directa a nivel nacional en América Latina. Un blance comparado 1978-2002', in Observatorio Electoral Latinoamericano [WWW document]. URL http://www.observatorioelectoral.org/ [accessed 26 July 2007]. 